\title{
HOW TO CREATE 'GENIUSES' IN GEOSCIENCE
}

\author{
THE FIELD OF GEOSCIENCE IS RAPIDLY EXPANDING \\ IN MANY PARTS OF THE WORLD, AS WE SEEK MORE \\ SOPHISTICATED WAYS TO GATHER ENERGY AND USE \\ NATURAL RESOURCES RESPONSIBLY. HOWEVER, \\ IT SUFFERS FROM A SHORTAGE OF NEW BLOOD, \\ ESPECIALLY PEOPLE FROM DIVERSE BACKGROUNDS. AT \\ TRITON COLLEGE IN ILLINOIS, DR SHELDON TURNER'S \\ GENIUS PROGRAMME AIMS TO CHANGE THAT
}

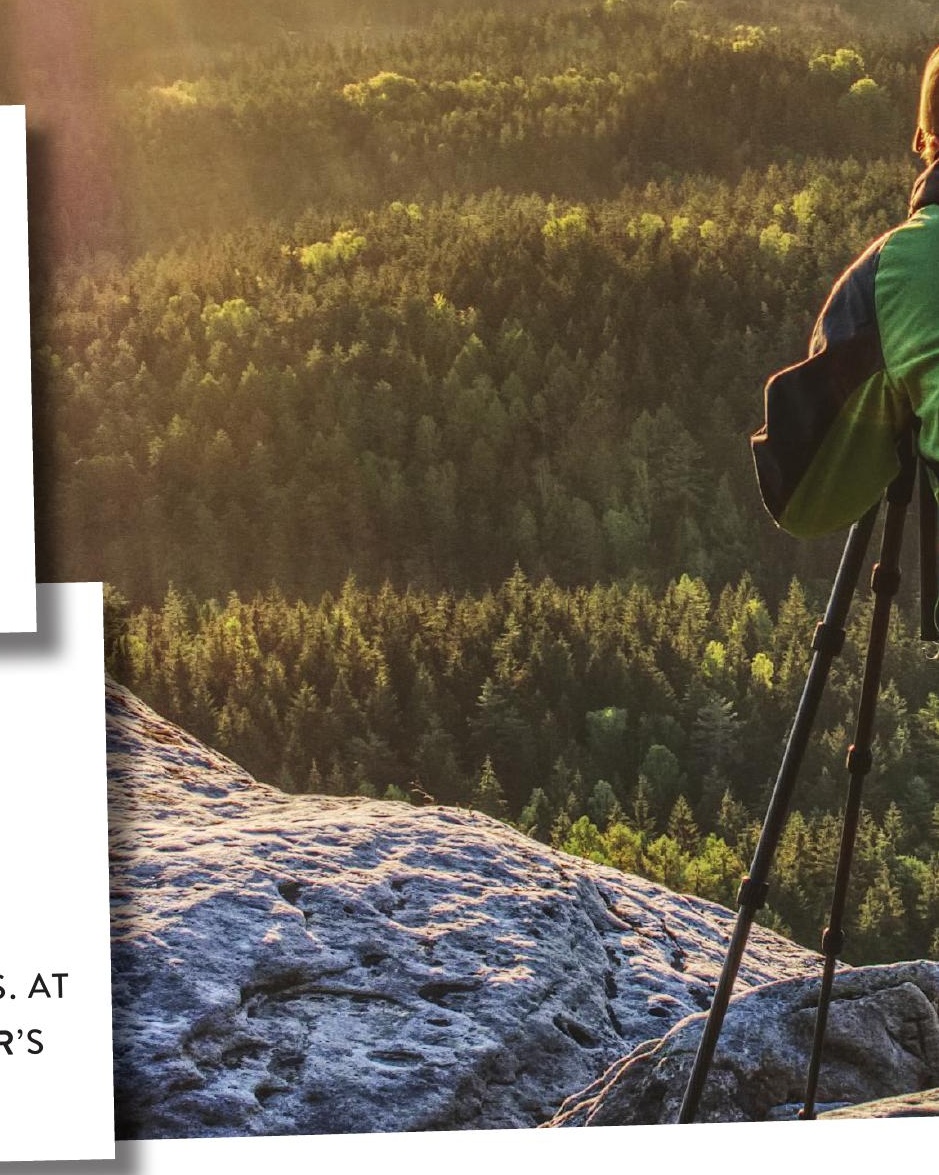

Dr Sheldon Turner heads the Triton GENIUS (Geo-Engineering Innovations through Undergraduate Scholarship) Program at Triton College in Illinois, USA. $\mathrm{He}$ is passionate about making geoscience accessible for all. The programme provides full-ride scholarships, along with intensive mentoring, for academically gifted students from low-income backgrounds to pursue careers in geology, environmental science, engineering and related fields. There is also the opportunity for hands-on research in the field.

\section{SEEKING SOCIAL CAPITAL}

"Both geoscience and related engineering careers are seeing a fast increase in

employment opportunities, while at the same time we are seeing shrinking enrolment in these areas within higher education," Sheldon explains. He says this is compounded by the lack of 'social capital' - the sense of belonging, trust and role models for students pursuing an education in an area in which they are underrepresented. Due to the lack of diversity in geoscience and STEM in general, he feels they do not accurately reflect the knowledge and needs of the communities they aim to serve.
This is especially pertinent in the state he calls home. "In Illinois, we have both rural agriculture and major urban areas right next to each other, each with their own set of environmental issues," he says. "Government bodies and private companies alike need people with the knowledge and skillsets to solve these problems."

Sheldon works with students mainly on water quality issues, but also points towards Illinois' role in the energy industry. "The state has a long history of fossil fuel production and continues to play a role in energy policy. From our electricity, to the water we drink, to the materials that build our homes and roads, Illinois' geoscientists and engineers are hidden heroes that most of the population doesn't even know exist, let alone see them as viable career role models."

\section{TAKING TO THE WATER}

Sheldon gets his students involved in tackling local issues like water pollution and flooding. "We've collaborated with civil engineers on projects dealing with the Chicago River, the most famous and populated river in the region," he says. "Next, we plan to do the same for the Des Plaines River, which flows right next to campus. Most of my students are well-acquainted with the effects of flooding, as every few years the front entrance of campus is underwater!"

Sheldon believes that students have an important role to play in collecting data about the river, and they also benefit from picking up important scientific skills along the way. "While students learn about how to collect and organise data, all important skills for new scientists, they are also making an impact on the future of their community," he explains. "Through sharing what they learn with friends and family, and creating a better awareness of our natural environment, they are making a positive impact on the future of their community."

\section{TURNING TO WORMS}

Sheldon emphasises the importance of a student-led approach in coming up with new ideas and putting them into practice. $\mathrm{He}$ cites a recent project: "One student had been collecting the water runoff from a worm compost bin for several years and wondered whether it could be used as fertiliser in a hydroponics system. We designed and built such a system, along with several other 

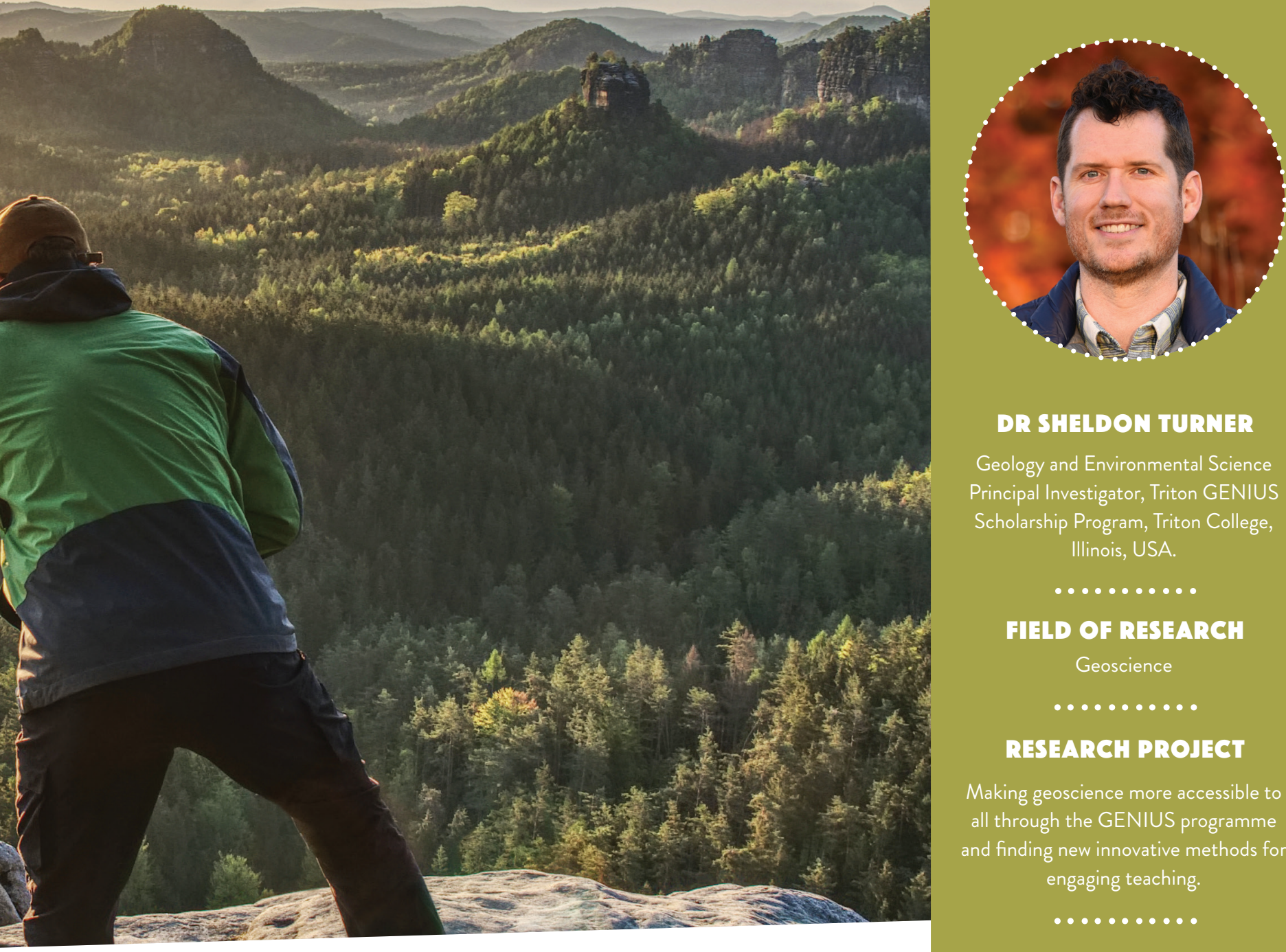

DR SHELDON TURNER

Geology and Environmental Science Principal Investigator, Triton GENIUS Scholarship Program, Triton College, Illinois, USA.

FIELD OF RESEARCH

Geoscience

\section{RESEARCH PROJECT}

Making geoscience more accessible to all through the GENIUS programme and finding new innovative methods for engaging teaching.

.........

\section{FUNDER}

National Science Foundation (NSF)

students, and the project eventually earned an award in a collegiate science competition. I've since procured much more sophisticated hydroponics equipment and am looking forward to continuing the project once the coronavirus pandemic is over." Sheldon is rightly proud of his students' achievements the hydroponics worm waste project saw them attending their first scientific conference and competing with students from prestigious universities - a great accolade for the GENIUS programme.

It is rare for students to be able to access experiences that involve carrying a project all the way through from an initial idea to fruition, especially within the early years of college. The GENIUS programme's ability to tap into this means that it creates scientists who are more engaged with the world around them, within the community rather than separate from it.

\section{MENTOR METHODOLOGY}

"The thing I love most about mentoring students through research rather than classroom-based learning is that it naturally becomes driven by the students' own inquiries," says Sheldon. "They learn so much more by experiencing the world directly rather than through a screen or a textbook." Sheldon keeps in touch with many ex-students once they graduate - many remain colleagues, largely due to their close collaboration and the supportive working relationships formed while carrying out research.

Sheldon believes it is important to treat students as colleagues rather than 'kids', especially given the range of ages in the community college setting. "They all have life experience and shouldn't be treated as blank slates, but rather taught to utilise the wealth of knowledge they already have."

\section{A RECIPE FOR SUCCESS}

"We've given out nearly 30 full-tuition scholarships thanks to the grant from the National Science Foundation (NSF)," says Sheldon. "We've also built some amazing partnerships with major universities such as Illinois Institute of Technology, which allow our GENIUS scholars to transfer with guaranteed scholarships."

They also reacted quickly to ensure students' welfare during the coronavirus pandemic. "When Covid-19 first came to the region, many students lost their jobs and were worried
This work is/was supported by NSF, under award

number 1741971 . The contents are solely the responsibility of the authors and do not necessarily represent the official views of NSF.

they wouldn't be able to remain in school. We worked quickly with NSF and our financial aid office to allocate extra funds to students to help with living costs, which many students have said were the reason they were able to pay rent."

Sheldon hopes the GENIUS programme will continue even after the NSF grant period ends and is working to make sure that Triton College is seen as a gateway to STEM careers. "This project is also teaching us about what works and what doesn't, so we are building a model we can share with other schools wishing to do something similar."

Sheldon's commitment to his students and to teaching geoscience is palpable. And the scholarship programme? It's genius! 


\section{ABOUT GEOSCIENCE}

Geoscience covers any scientific discipline that deals with the Earth. This includes exploring the materials that are found within the Earth, how they got there, and the interplay between the planet's natural systems. Sheldon ardently believes it is a field that should be open to anyone with a passion for the subject, and he explains why.

\section{WHY ARE YOU SO PASSIONATE}

ABOUT INCLUSION IN GEOSCIENCE? All disciplines improve with improved diversity. Science's goal is to be objective, but our human experiences shape the questions we ask - and we need to ask a diverse range of questions. Geoscience is one of the least diverse STEM fields in the USA, and place-based knowledge is crucial for finding sustainable solutions. We need to empower people to understand and advocate for their own community instead of relying on outside help.

WHAT DO YOU FIND CHALLENGING ABOUT GEOSCIENCE?

I find geoscience to be a very spatial field,

\section{HOW TO BECOMEA GEOSCIENHIST}

Geoscience can be an undergraduate qualification in itself, but often elements of it are incorporated within other subjects, such as geology, Earth sciences, or some engineering courses.

- According to the QS Top University Rankings, the best universities for Earth sciences are ETH Zurich, MIT, Harvard, Cambridge and Oxford.

There are plenty of apprenticeships available in the field of geoscience. This can be with organisations such as governmental environment bodies, energy companies, and consultancies.

- According to Indeed, the average annual salary for a geoscientist in the USA is $\$ 72,709$, but given the wide range of geoscience roles, salaries vary considerably. meaning we need to able to visualise things in three or even four dimensions. We have to be good at imagining the unseen, as lots of the things we deal with are invisible, underground, or happened a long time ago.

\section{WHAT ARE THE MOST PRESSING} ISSUES FACING GEOSCIENTISTS? I believe the two biggest challenges for society are how to source energy without exacerbating climate change, and how to ensure our communities have reliable clean water. Geoscience has the answers for both questions, but the biggest challenge for us is explaining to the public how we can help. Scientists are often not great at communicating science to politicians or the general public. We cannot afford to be bad communicators when the future of our planet is at stake.

\section{WHERE DO YOU SEE YOUR OWN} RESEARCH LEADING NEXT?

I will always focus on improving science education and making it more accessible to more people. I will continue to collect and analyse data to determine how to best teach outdoors, how to guide students through projects, and especially the unique characteristics of teaching adults rather than children.

\section{DOES TRITON OFFER ANY OTHER}

PUBLIC OUTREACH SCHEMES?

Yes! We have a very active continuing education department for the community. We also have the Cernan Earth and Space Centre, which runs lots of science camps for school-aged children and hosts forums for the community. We commonly host career fairs with local businesses.

\section{PATHWAY FROM SCHOOL TO GEOSCIFNIST}

Sheldon says that a solid foundation in mathematics is a must. Many geoscience courses require one to two science subjects as well. Sheldon also recommends subjects such as art, computer science, philosophy and logic, which will help give a more wellrounded preparation.

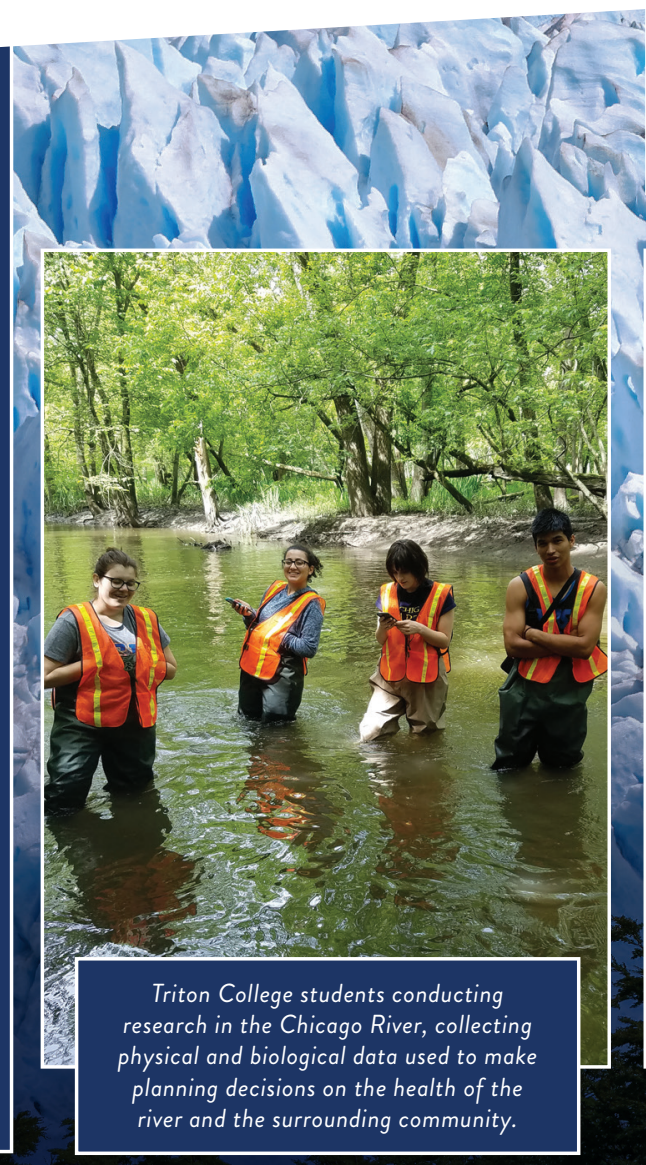




\section{SHELDONH" TOP TIPS FOR STUDENIS}

01 - Stop thinking that science is for other people. Your questions about the natural world are important and science is a process that anyone can learn. It isn't about memorising facts; it is about going out and discovering new ones.

02 - Maths can be challenging but is important. Eventually, it will help you solve real problems when you apply it in a scientific way.

03 - Science is the best way to learn something new that no-one has ever learned before. It adds to our knowledge as a species and can make the world a better place for everyone.
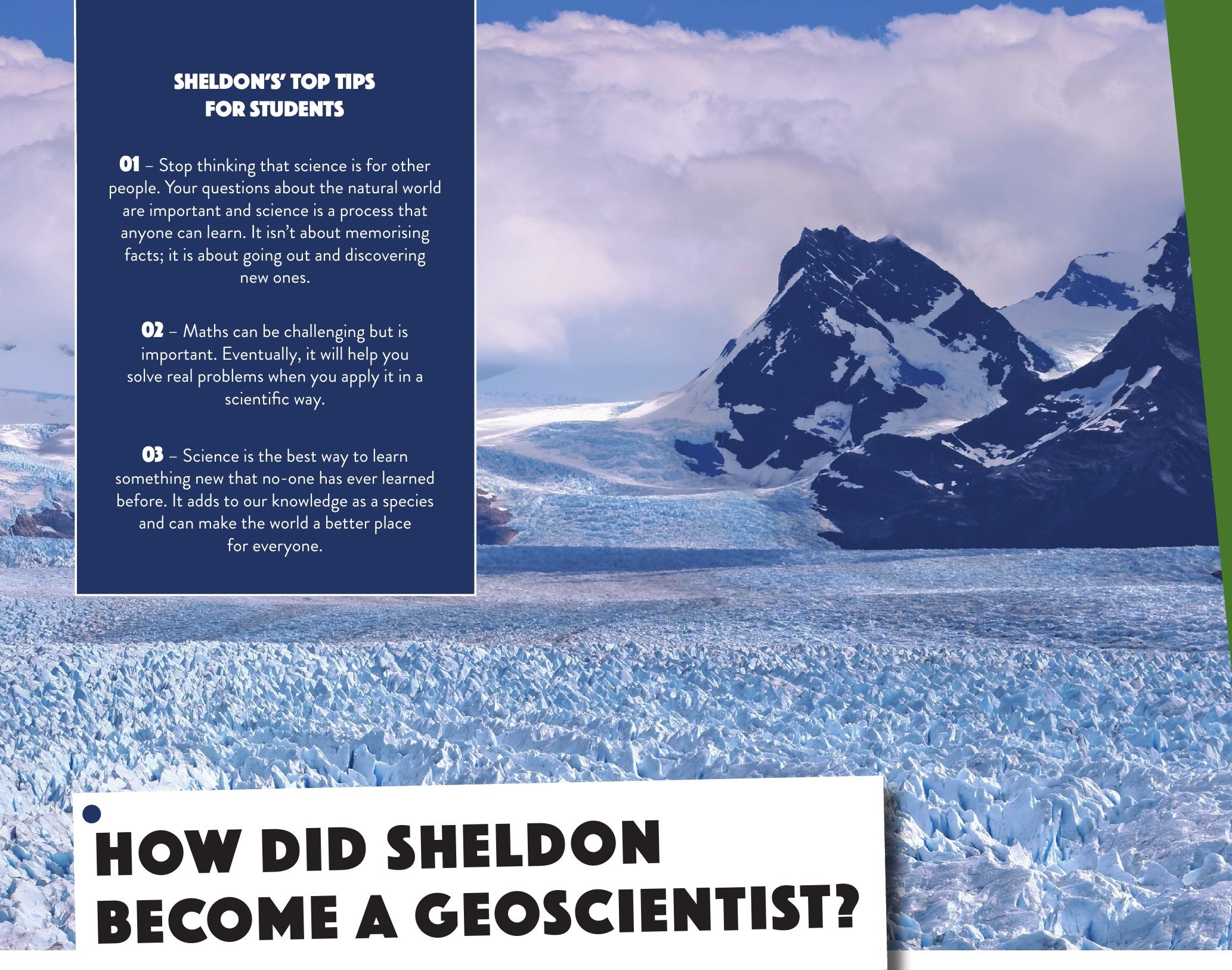

WHAT WERE YOUR INTERESTS AS

A CHILD?

I always loved dinosaurs and nature. I didn't end up as a palaeontologist, but $I$ at least get to teach about dinosaurs and evolution, and how they relate to modern society. I grew up near a river and my family spent every weekend in it, which I am sure is where my love of water science comes from.

\section{WHAT INSPIRED YOU TO FOLLOW A} CAREER IN GEOSCIENCE?

I didn't know about geoscience before college, as it isn't part of the core curriculum in my home state. In my first year of college, I took a class focusing on Mars that was taught by a geology professor. I became hooked. A geology field trip to Utah, in a landscape very different to the cornfields of my childhood, helped reinforce this.

\section{WHERE HAS YOUR CAREER}

TAKEN YOU?

I've travelled across the USA, Canada, Ireland and the UK as part of my geoscience education. I love being able to travel somewhere new and figure out the history of the scenery I see. There is something majestic about piecing together the story behind the formation of a mountain, a desert or a volcano. Before l'd finished studying, I knew that sharing these experiences with others would be my life goal. That's what led to me focusing on geoscience education research for my doctorate, and the rest is history!

WHAT ATTRIBUTES HAVE HELPED YOU BECOME A SUCCESSFUL SCIENTIST?

Imagination. As a scientist, you need to connect things that others might think are unrelated. Experiences from one part of your life - a random class, an experience at a museum, or an interesting book - can be applied elsewhere and help solve real problems. Logical and critical thinking is important for research, but imagination is most important for kicking off the process.

\section{HOW DO YOU OVERCOME}

OBSTACLES IN YOUR WORK?

I remind myself that I am solving real problems for real people, even if my work seems abstract at the time. I also remember to recognise the challenges faced by my colleagues and students. As a straight, white, cis-gendered male, I haven't experienced the same obstacles in my career that many of my colleagues have. It's important to listen to others and not be dismissive. I think some machismo remains in geoscience that could be pushing away people who don't look like me. I want to change this and make geoscience an inclusive discipline where all can succeed.

\section{WHAT AMBITIONS DO YOU STILL HAVE} TO ACHIEVE?

With a growth mindset the work never ends, as there are always new things to discover, new problems to solve, and new students to teach and learn from. I'd like to see diversity in STEM reflect the general population, first in my own community but ultimately at a global scale. Obviously, that's too much for just one person, but if I can move the needle just a little, I'll know I did my best. 